\title{
Research on Confucius's view of students as Instruction knows no class distinction
}

\author{
Shuyan $\mathrm{Yi}^{1,}$, , Mingzhu $\mathrm{Fu}^{2, \mathrm{~b}}$ \\ ${ }^{1}$ College of Humanities \&Sciences of Northeast Normal University, Changchun 130117, China; \\ ${ }^{2}$ School of Jingyue Nanhuan Primary School, Changchun 130033, China. \\ ayishuyan2013@126.com, b770864076@qq.com
}

Keywords: Confucius, view of Students, Instruction knows no class distinction, Education.

\begin{abstract}
In order to restore the rites of Zhou Dynasty and practice the ideal of "benevolence", Confucius regards "moral education" as the basis of his carrying out education. In the course of his education, Confucius established the view of students as Instruction knows no class distinction. Based on the analysis of Confucius's disciples, summed up the educational guiding ideology of Confucius, and the conclusions are as follows: to the studious students, Confucius insists on the principle of perfectionism, and try to shape them as perfect examples; to the general character students, Confucius uses the principle of education, educated them to develop their talents. In short, in the process of education, Confucius's pursuit of the maximum number of educational objects and the diversification of educational methods, in order to realize the optimization of his training effect of "gentleman".
\end{abstract}

\section{Introduction}

Confucius is a famous thinker, educator and founder of Confucianism in ancient China. The core of Confucius's thought is advocating "benevolence and righteousness", he advocated the restoration of "rites and music" and insisted on the strategy of running the country by virtue and morality, and thought that the harmonious society should be "the people take the monarch as the heart, and the monarch takes the people as the body". As a great educator, Confucius devoted all his life to the promotion and popularization of his theory. Whether it is in the ordinary behavior or engaged in the teaching and learning of special behavior, Confucius was able to adhere to the concept of execution to be implemented, seriously, truly "unity of knowledge and practice". [1]

In the aspect of life, Confucius adhere to the "benevolence" as the foundation. He thinks that everyone's nature is good, and education can make anyone good. He insisted on the development views to the peoples and things, and don't give up teaching the people because they are unreasonable. This behavior reflects Confucius's educational principles as Instruction knows no class distinction.

Because of Confucius's insistence on benevolent ideals, and the implementation of the rulers "hegemony" theory is not consistent, and this makes Confucius has very little room in his political development. The political frustration has led Confucius to focus most of his energy on education. In the teacher's role, Confucius still adhere to the principle of his education. When selecting students, he has no special provisions for the identity of the students, for student's age, personality and no strict boundaries. As long as people who want to learn the traditional culture and the ritual music, just giving the appropriate gift, Confucius would be tireless teachings to them. Although Confucius disciples under the door of different origin, and academic level uneven, Confucius would be based on their characteristics of the class to teach carefully. As Nobel Prize winner Dr. Li Yuanzhe said: "Confucius deeply recognized that the main body of education is to learn the students, the students' learning is far more important than the teacher's teaching, so he also has a deep understanding of the student's guidance and inspiration".

Confucius had more than 3 thousand disciples, there are seventy-two people who were known as the sage, among which there are not only have the royal family and senior officials, but also civilians. [2] In the teaching process, Confucius can teach students in accordance with their aptitude, and 
according to the student's personal conduct, qualifications, the implementation of educational strategies, and the specific analysis is as follows:

\section{Cultivation of gentleman}

Restricted by the social conditions at that time, most people could not concentrate on reading. Even though there are numerous of disciples learned by Confucius, but only few students excellent in character and learning, Only Yanhui, Zigong, Zixia, Ziyou et al. To this kind of excellent in character and learning disciples, Confucius appreciate them very much, and would often praise and encourage them, in order to establish a learning example for other disciples.

Yan Hui is the most studious and the most satisfactory disciple of Confucius, and their freemasonry friendship was widespread, and become the education sector of the story. According to statistics, in the analects, Yan Hui appeared in a total of 20 times, including 5 times recorded his conversation with others, 14 others of his evaluation, and which a positive tribute to him are basically. In the evaluation of Yan Hui, a number of which is Confucius's words of praise, such as "Yan Hui is really a sage! A piece of bread and a cup of water, in the alley, people back unendurable, also look for release through the pain", "With me I will act, give up I hide, only me and you have this practice", "Don't vent on others, can correct the errors in time", etc. ${ }^{[3][4]}$ From the present can be seen in the material, Confucius never had the slightest criticism to Yan Hui. The reason is that Yan Hui is really interested in learning manners, able to apply knowledge into his daily life and good at learning, he is the model thought by Confucius as "Those who know it are not as good as those who love it; those who love it are not as who delights in it."

Yan Hui has a very high learning and understanding, and after Confucius's advice, he could not only learn by analogy, also achieved a "smell to know ten" state. It can be seen from Yan Hui's experience that it is based on the "love" consciousness, Confucius love this modest, refined and cultured, courtesy of contented in poverty and devoted to things spiritual students.

In the course of learning, such a talented, gentle personality, studious students will take the initiative to ask Confucius questions, and for Confucius's attention to all kinds of moral cultivation will also be very seriously, and he also attaches great importance to Confucius's moral cultivation. According to the Analects of records, a total of seven people asked Confucius about "kernel ", and Yan Hui is one of them.

Zigong is another virtue of Confucius's students. Zigong is an inquisitive student, the inquiry relates to "politics", "Shi", "gentleman", "friends" and other aspects. About how to become a "Scholar", Zigong asked Confucius continuous questions three times, Confucius respectively from the country, family, personal perspectives give a clear answer. After Confucius patience, a series of detailed reply, Zigong on how to become a "Scholar" fuzzy understanding was finally clear. Not only that, in the process of listening to Confucius lecture, his thinking is also very active, can at any time according to their own understanding of the status of questions. His inquisitive spirit to cultivate his unique knowledge play an important role, and which is an important reason for him to be able to engage in politics. It is only because Confucius was able to respect, care for students of this personality, and to actively guide in their process of growing, which makes them have made great achievements in their later careers.

This kind of smart studious students are not only good at asking questions, thinking, but also have greatly admiration to Confucius's knowledge and learning. Zigong praised Confucius as "he is the sun and the moon, cannot be more than", while Yan Hui expressed his great admiration for Confucius as "His moral and knowledge is too high to be reached. ". After Confucius's guidance, it is only for honor the teacher and respect his teaching beliefs, they could play their strengths, and eventually become a model for students.

In short, in the process of teaching this kind of disciple, Confucius and students is a harmonious teacher-student relationship. He tended to implement "benevolence" and "ceremony" of the overall 
moral education, and try to use his own practical action to train students to become a gentleman with both ability and integrity.

\section{Pay attention to the personal expertise of students with poor congenital qualifications}

Generally speaking, people with high intelligence and good personal qualifications are more likely to succeed. But intelligence is not the only factor in success. Even if a person with poor congenital qualifications, but through his personal efforts and the mentor's carefully teaching, he also can be success in some field. Confucius has many disciples and most of them belong to the disciple's qualification relatively mediocre ordinary people. But after Confucius's teaching and individual efforts, of which there are a lot of people have made remarkable achievements in some area, with $\mathrm{Zi} \mathrm{Lu}, \mathrm{Gao}$ Chai and Zeng Can as the representative. In this regard, $\mathrm{Zi} \mathrm{Lu}$ is the most representative. He belongs one of Confucius's famous students of the "si ke shi zhe", and made outstanding achievements in politics. His success is not only related to his personal initiative, but also has a direct relationship with Confucius's ability to teach students according to their individual differences. ${ }^{[5]}$

$\mathrm{Zi} \mathrm{Lu}$ is a person with straightforward character, He advocates the chivalrous personality and his personality is very prominent. He had bullied Confucius, but after realizing the greatness of Confucius, he volunteered to be a disciple of Confucius. After learning form Confucius, Zi Lu did not blindly obey the teacher, he treated Confucius with a critical eye in most cases.

Although Confucius is committed to restoring the "rites and music ", but as a broad-minded teacher, he did not simple and crude denial $\mathrm{Zi} \mathrm{Lu}$ because of his speech on the collision, But able to looking for his flash point. Through careful observation of his daily behavior, Confucius appreciated his loyalty, faith and commitment, and thought he was the representative of keep a promise inviolate, also was the spokesman "Righteousness" and "faith". After a thorough understanding of $\mathrm{Zi} \mathrm{Lu}$, Confucius took a "Frank" approach to education. When he has a good performance, Confucius would be in a timely manner to his affirmation; at the same time, in order to prevent him from breeding pride, Confucius would promptly pointed out the shortcomings of his existence. In terms of personality, Confucius believes that $\mathrm{Zi} \mathrm{Lu}$ should developing in the political road, and pay attention to the cultivation of his ability in the process of education.

After Confucius's careful guidance, $\mathrm{Zi} \mathrm{Lu}$ changed his image from a boorish fellow to a practicing "benevolence" and "propriety" scholar, and eventually become a prominent person. Although he is not a fully refined gentleman, but the spirit what he showed in times of crisis was enough to prove his greatness.

\section{Carry out filial piety education to those with low moral character}

These two types of disciples are noble moral character, for this disciple Confucius can combine their own advantages to promote the implementation of ritual music enlightenment. Among Confucius's disciples, not all of them have a noble character, as well as a class of disciples with poor character abilities, Zai Wo, Ran Qiu, Yuan Rang and Zi Zhang all belong to this kind. [6] Although their moral qualities far from the requirements of Confucius, but Confucius did not give up this type of students, while pay attention to their filial piety education, and made many of them have some achievements. Such as Zai Wo, he finally became an outstanding achievement in the field of speech.

Filial piety is one of the most important contents in the ritual system, and Confucius thought that filial piety is the foundation of humanity. In the Analects, Confucius repeatedly talked about filial piety, and gave enough explain on what is "filial piety" and how to achieve "filial piety". In a word, "filial piety" is reflected in the details of the behavior of the son to the parents.

The ancients believed that after the death of their parents, the son needed to observe the funeral day to show their filial piety to their parents. But Zai Wo thought it is an excessive etiquette requirements, and three years of observe mourning for his parent is too long, the time should be reduced to one year. To his mistake, Confucius did not directly deny him in the dialogue process, while asked him if he can comfortably "eat rice" and "wear beautiful clothes" only a year after the death of his parents. After Zai 
Wo gave me a definite answer, Confucius did not comment on it, nor did he try to persuade him. Through this thing, Confucius have a deep understanding to Zai Wo, and gave an evaluation to him as "inhumane". In addition, Zai Wo also has a bad habit of sleeping during the day. His behavior greatly touched Confucius, changed

Confucius's view to person, from "listen to a person and believe what he says" to "observe his actions and believe what he says". From Confucius to his attitude, we can see that Zai Wo is a person skilled in debate. Even so, Confucius still didn't give up Zai Wo, but to make use of his advantages. In his travels around the world, Confucius often sent Zai Wo to other countries, so that it can give full play to his ability.

\section{Summary}

After Confucius was cognizant of the law as "The human's nature is good at the time of they were born, the difference between each other is very small; in the later growth process, affected by the environment, the difference between people would be greater and greater", He began to realize the importance of Education. In view of the current situation that only nobles can receive education, Confucius tried to break the monopoly of education through the establishment of private education, as far as possible to bring more people into the ranks of Education. In the process of the implementation of education, Confucius adhere to the light of its general trend, through encouraging students to develop self-confidence and pointing out the shortage of students through criticism help them improve their abilities, so as to create unlimited space for progress and development for the students. In the end, many of his disciples have achieved good results. Such as the "seventy-two wise men", they are all the elite talents in various industries. Confucius's practice has important reference significance for today's implementation of inclusive education [7]. In addition, Confucius adhered to the act in accordance with the "benevolence" and "courtesy" of the principle of acting. Under the support of this kind of idea, Confucius practiced his creative education concept, and created the great era of Chinese education. [7]

\section{Acknowledgments}

This paper is funded by the project of the Jilin Academy of Educational Sciences, and the project name is "study on the reform of Participatory teaching method in Ancient Literature ".

\section{References}

[1]. G.J. Yang, Notes for the spring and Autumn Period, Zhong Hua Book Company, Beijing, 1990, p.1197.

[2]. S.Q. Wang, Studies on disciples' thinking modes of Confucius based on"Analects of Confucius". Journal of Nanchang College of Education. (2013) No.11, p.19-21.

[3]. G.J. Yang, Translation and annotation for The Analects of Confucius, Zhong Hua Book Company, Beijing, 1980.

[4]. K.Y. Dong, A historical study of the history of Chinese ancient education. Journal of Hebei Normal University (Educational Science Edition. (2013) No.5, pp.25-29.

[5]. M.J. Shi, The concept of "learning" in Confucius's educational thoughts. Journal of Shandong Administration Institute and Shandong Economic Management Personnel Institute. (2013) No.8, pp.137-139.

[6]. J.J. Kong, Discuss on the basic characteristics of Confucius's educational dialogue speech mode. Confucius Studies. (2007) No.7, pp.19-26.

[7]. S.Y. Yi, N. Liu, Y. Xu, Exploring of Confucius's Teaching Mode and the View of Teachers and Students. Advances in Social Science Education and Humanities Research, Vol.87(2007), pp.616-619 